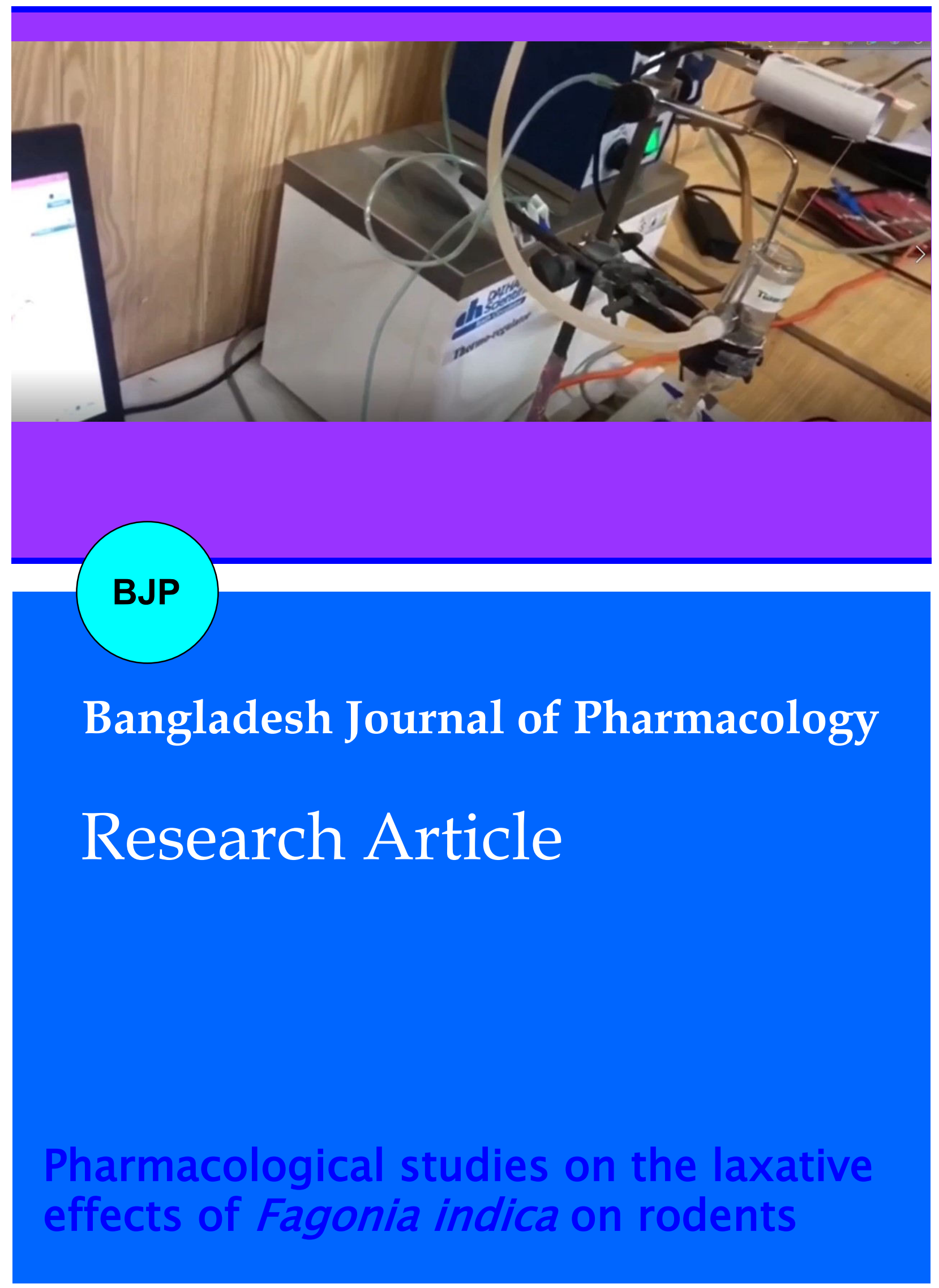




\title{
Pharmacological studies on the laxative effects of Fagonia indica on rodents
}

\author{
Muhammad Zeeshan Ali ${ }^{1}$, Malik Hassan Mehmood ${ }^{1}$, Muhammad Saleem ${ }^{\mathbf{1}}$ and Anwarul- \\ Hassan Gilani ${ }^{2}$ \\ ${ }^{1}$ Department of Pharmacology, Faculty of Pharmaceutical Sciences, Government College University, Faisalabad- \\ 38000, Punjab, Pakistan; ${ }^{2}$ The University of Haripur, Haripur, Khyber Pakhtunkhwa, Pakistan.
}

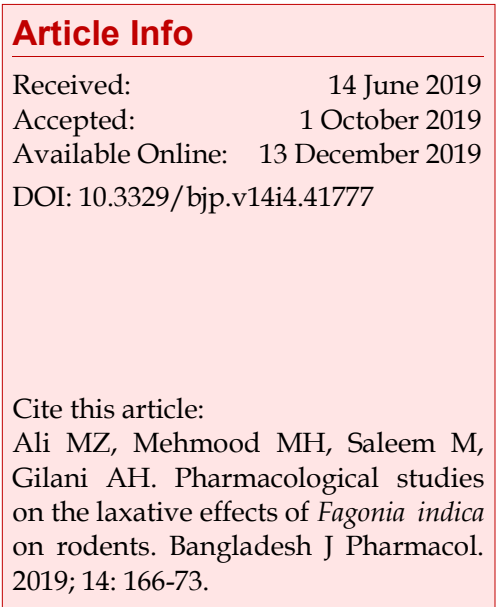

\begin{abstract}
This study explores the pharmacological basis for the folk use of Fagonia indica in constipation using in vivo and in vitro assays. The crude extract of F. indica contained tannins, saponins, anthraquinones, alkaloids, flavonoids, glycosides and phenols. The administration of F. indica extract (100 and $300 \mathrm{mg} / \mathrm{kg})$ to mice caused a partially atropine-sensitive 35 and $42.6 \%$ laxation, respectively, similar to ursolic acid which showed 22 and $36 \%$ laxation at 10 and 30 $\mathrm{mg} / \mathrm{kg}$, respectively. In loperamide-induced constipation mice, F. indica (27.3 and $34.6 \%)$ and ursolic acid (15 and $28 \%$ ) also displayed laxative effects at the aforementioned doses. In mice and rats ileum, F. indica, its fractions (ethyl acetate, aqueous) and ursolic acid produced atropine-sensitive stimulatory effects, while in rats ileum, F. indica and aqueous fraction showed partially atropine-sensitive effects. F. indica and ursolic acid possess laxative and species-specific gut stimulant effects predominantly involving the activation of muscarinic receptor, thus eliciting its folk use in constipation.
\end{abstract}

\section{Introduction}

Constipation is a common bowel disorder characterized by fewer than three bowel movements/week, hardened stool and incomplete defecation. Herbal medicines are beneficial over the drugs as they modify the stool consistency to make defecation easier rather than to defect the neuromuscular function of bowel, which produces undesirable effects. Variety of medicinal herbs are popular for the treatment of constipation like Oligochaeta ramose (Hussain et al., 2014), Carissa carandas (Mehmood et al., 2014), Croton penduliflorus (Ashafa et al., 2012), Ficus carica (Lee et al., 2012), Chrozophora prostrate (Arshad et al., 2012), ispaghula (Mehmood et al., 2011) and ginger (Ghayur and Gilani, 2005).

Fagonia indica Burm. F. belongs to the family Zygophyllaceae, commonly known as dhamaaso or dhamaasa (medicinally) and dhama boti or saachi boti (in Urdu). It is a small spiny undershrub, mostly found globally in warm and arid regions (Gulshan et al., 2012; Ageely et al., 2014).

Numerous phytochemicals have been isolated from the $F$. indica such as $\beta$-amyrin, lupeol, $\beta$-sitosterol and faganilin (Farheen et al., 2014), quercetin, kaempferol, ursolic acid, nahagenin, hederagenin, pinatol (Atta-urRahman et al., 1984), diosgenin, kryptogenin, lanosterol, harmine, fagogenin, fagonin, oleanolic acid, harman, chinovic acid, genin $\mathrm{A}, \mathrm{B}, \mathrm{C}$ and riboflavin $\left(\mathrm{B}_{2}\right)$ niacin ( $\left.B_{5}\right)$, ascorbic acid (Eman, 2011; Kasture et al., 2014). This herb is bitter. However, it has been used in traditional system of medicine in numerous diseases like asthma, fever, anorexia, jaundice, constipation (Ahmad et al., 2014), vomiting, indigestion, dysentery and bodyache (Gulshan et al., 2012; Farheen et al., 2014).

It has been reported for anti-inflammatory, antioxidant and hepatoprotective (Shehab et al., 2015; Azam et al., 
2018), antifungal (Soliman et al., 2017), antipyretic (Ahmad et al., 2014), analgesic, antimicrobial (Sharma et al., 2009) and anti-cancer (Waheed et al., 2012) effects. To the best of our knowledge, no scientific report is available to rationalize its medicinal use in constipation. This study provides scientific evidence of its folkloric use in constipation.

\section{Materials and Methods}

\section{Plant collection, identification and extraction}

F. indica was collected from the vicinity of Shorkot City, District Jhang, Punjab, Pakistan. The plant material was authenticated by the expert taxonomist Dr. Mansoor Hameed, Department of Botany, University of Agriculture, Faisalabad. The specimen (voucher No. 1017-2015) was preserved at the herbarium of University of Agriculture, Faisalabad. A total of $5 \mathrm{~kg}$ whole plant was shade dried, coarsely powdered and then subjected for extraction with aqueous-methanol (30:70) for 7 days at room temperature with occasional forceful shaking. The slurry was passed through a muslin cloth to remove any debris material and then through Whatman qualitative grade No. 1 filter paper. The residue was reextracted twice and the supernatant(s) were combined and the extract was evaporated under reduced pressure in a rotary evaporator (Stuart RE 300, Cole-Parmer Scientific Experts, UK) at $35-40^{\circ} \mathrm{C}$ temperature to obtain the crude extract (yielding, $9 \% \mathrm{w} / \mathrm{w}$ ).

For polarity based solvent-solvent extraction, $25 \mathrm{~g}$ of the extract was dissolved in $150 \mathrm{~mL}$ of distilled water and the equal volume of petroleum ether was added. The combined solution was shaken vigorously in a separating funnel, the layers were allowed to separate. The upper layer (petroleum ether) was removed and petroleum ether was added in the remaining solution to repeat the process thrice. Petroleum ether layers were isolated and pooled together for evaporation to acquire the petroleum ether fraction. Chloroform was then added to the remaining aqueous solution and again shaken vigorously, in isolated layers, the lower layer (chloroform) was collected and the same procedure was repeated three times to achieve chloroform layers which were subsequently subjected for evaporation to obtain the chloroform fraction. The remaining layer was again treated in a similar fashion with ethyl acetate to obtain ethyl acetate fraction and the final remaining layer was evaporated to achieve the aqueous fraction.

\section{Phytochemical analysis}

The crude extract was subjected to identify the presence of phytochemical classes like tannins, saponins, anthraquinones, alkaloids, flavonoids, glycosides and phenols following the standard methods (Victor and Chidi, 2009).

\section{Animals}

Bulb/c mice (20-25 g) and Sprague-Dawley rats (200$250 \mathrm{~g}$ ) of either sex were used. They were housed under controlled room temperature of $25 \pm 2{ }^{\circ} \mathrm{C}$ and relative humidity of $60 \pm 5 \%$ at the animal house of the Faculty of Pharmaceutical Sciences, Government College University, Faisalabad. Animals were given standard diet and were kept on overnight fasting with free water before the experiment.

\section{Standard chemicals}

Acetylcholine perchlorate, ursolic acid and carbachol were purchased from the Sigma Chemicals Co. (USA). Atropine sulfate was obtained from the Highnoon Laboratories Ltd (Pakistan). Chemicals used for making the physiological salt solutions were sodium chloride (Sigma Chemicals Co.), calcium chloride and glucose (BDH Laboratory Supplies, England), magnesium chloride, sodium bicarbonate and sodium dihydrogen phosphate (Merck, Germany). Isoflurane was purchased from the local pharmacy. All the chemicals were of analytical grade and dissolved in distilled water.

\section{In vivo experiments}

\section{Laxative activity}

Mice were divided into 11 groups ( $n=6 /$ group). They were placed in plastic cages. One group (negative control) received normal saline orally $(10 \mathrm{~mL} / \mathrm{kg})$. The second group received carbachol (1 mg/kg) intraperitoneal. The third and fourth groups received 100 and $300 \mathrm{mg} / \mathrm{kg}$ dose of the crude extract of F. indica. The animals of fifth and sixth group received 10 and 30 $\mathrm{mg} / \mathrm{kg}$ of ursolic acid orally. The remaining groups received the pre-treatment of atropine $(10 \mathrm{mg} / \mathrm{kg}$, intraperitoneal) and the same doses of carbachol, crude extract of F. indica and ursolic acid were administered for the reassessment of laxative effect (Mehmood et al., 2014).

\section{Loperamide-induced constipation}

Mice were divided into six groups ( $n=6 /$ group) and kept in plastic cages. The first group of mice served as negative control and received saline $(10 \mathrm{~mL} / \mathrm{kg})$. The second to sixth groups were injected loperamide $(5 \mathrm{mg} /$ $\mathrm{kg}$ ) intraperitoneally one hour before any treatment. The second group served as disease control which received no treatment, while the mice in treatment groups (third and fourth) were administered the crude extract (100 and $300 \mathrm{mg} / \mathrm{kg}$ ) orally. The fifth and sixth groups of mice received ursolic acid (10 and $30 \mathrm{mg} / \mathrm{kg}$ ) orally. After 8 hours, total feces production (total number of wet feces plus the total number of dry feces) was measured and the percentage of wet feces [\% laxation $=$ total number of wet feces/number of total feces $\times 100$ ] was considered as a laxative effect (Kakino et al., 2010). 


\section{Acute toxicity}

Mice were divided into four groups ( $\mathrm{n}=6 /$ group). They fasted overnight with free access to drinking water only. The mice of first group received saline $(10 \mathrm{~mL} /$ $\mathrm{kg}$ ), while the mice of next three groups (second, third and fourth) received the increasing doses of extract $(3,5$ and $10 \mathrm{~g} / \mathrm{kg}$ ). All mice were kept under observation for any sign of toxicity or behavioral change, tremor, salivation, seizure, sleep, or coma for 6 hours. However, the lethality was observed for up to 24 hours.

\section{In vitro experiments}

\section{Preparation of rat and mice ileum segments}

The rats and mice were euthanized for isolation of ileum preparations followed by deep anesthesia with isoflurane $(2-5 \% \mathrm{v} / \mathrm{w})$ by inhalation in a closed jar. The abdomen was dissected out, required tissues were identified, cleaned of mesenteries and isolated. Individual tissues of 2-3 cm were mounted in $10 \mathrm{~mL}$ tissue organ baths containing Tyrode's solution, maintained at $37^{\circ} \mathrm{C}$ and aerated by carbogen $\left(95 \% \mathrm{O}_{2}\right.$ and $\left.5 \% \mathrm{CO}_{2}\right)$. A preload of 0.7-1.0 g was applied to individual tissue and the responses of different challenging concentrations of the crude extracts on ileal tissues were recorded using isometric force transducers coupled with PowerLab data system (ML4/25, ADInstruments, Australia). Each tissue was allowed to equilibrate for $30 \mathrm{~min}$ before the addition of any test material and then stabilized with repeated administration of acetylcholine $(0.3 \mu \mathrm{M})$ at every 3-5 min interval until similar responses were achieved.

To evaluate the possible stimulatory mechanism, the plant extract, its fractions and ursolic acid were screened on rat and mice ileum in presence and absence of atropine $(0.1 \mu \mathrm{M}$, a cholinergic antagonist), pyrilamine ( $1 \mu \mathrm{M}$, a histaminergic receptor antagonist), and methysergide $(1 \mu \mathrm{M}$, a serotonergic antagonist) (Mehmood et al., 2014). Complete or partial blockade of the stimulatory effects of test materials in presence of any of aforementioned antagonist(s) elicits the involvement of respective pathway(s) in the excitatory effect of the test material.

\section{Statistical analysis}

All values were expressed as mean \pm Standard error of mean. Student $t$-test/ or One-way analysis of variance (ANOVA) followed by Dunnett's test or Bonferroni test were applied for differentiation of data of laxative activity. Calculations, statistics and graphing were performed by using Graph Pad program (USA).

\section{Results}

\section{Phytochemical analysis}

Preliminary phytochemical screening of crude extract indicated the presence of tannins, saponins, anthraqui- nones, alkaloids, flavonoids, cardio-active glycosides and phenols.

\section{In vivo experiments}

\section{Laxative activity}

F. indica at the dose of 100 and $300 \mathrm{mg} / \mathrm{kg}$ resulted in 35 and $42.6 \%$ production of wet feces in mice, respectively, similar to the effect of ursolic acid (10 and $30 \mathrm{mg} / \mathrm{kg}$ ) which exhibited 22 and $36 \%$ laxation, while carbachol showed $48.5 \%$ laxation at $1 \mathrm{mg} / \mathrm{kg}$. The saline treatment produced only $13 \%$ wet feces. When the laxative effects of $F$. indica (100 and $300 \mathrm{mg} / \mathrm{kg}$ ), ursolic acid (10 and $30 \mathrm{mg} / \mathrm{kg})$ and carbachol $(1 \mathrm{mg} / \mathrm{kg})$ were restudied in mice pretreated with atropine $(10 \mathrm{mg} / \mathrm{kg})$, the percent production of wet feces were significantly $(\mathrm{p}<0.05-0.01)$ dropped down to $28.1,33.2,14,24$ and $27.2 \%$, respectively (Table I).

\section{Loperamide-induced constipation}

In the loperamide-induced constipation model, loperamide fed mice showed a significant decrease $(p<0.01)$ in the mean fecal defecation and \%wet feces production $(4.8 \%)$ compared to the saline treatment group. Administration of crude extract $(100$ and $300 \mathrm{mg} / \mathrm{kg})$ and ursolic acid caused marked increase $(p<0.05-0.01)$ in mean fecal output and \%wet feces production when compared with only loperamide-administered animals (Table II).

\section{In vitro experiments}

\section{Effects on rat and mice ileum}

In isolated rat ileum, the crude extract $(5-10 \mathrm{mg} / \mathrm{mL})$ and ursolic acid $(0.003-0.1 \mu \mathrm{M})$ produced a concentration-specific stimulant effects reaching its maximum of $53.3 \pm 1.6$ and $45 \pm 2.9 \%$ (\% mean \pm SEM, $n=4-6$ ) of acetylcholine $(0.3 \mu \mathrm{M})$-induced contraction at $10 \mathrm{mg} /$ $\mathrm{mL}$ and $0.1 \mu \mathrm{M}$, respectively. To further characterize, the stimulatory effects of $F$. indica and ursolic acid were restudied in rat ileum preparations pre-treated with atropine $(0.1 \mu \mathrm{M})$. The stimulant effects of $F$. indica were found partially sensitive to atropine, while ursolic acid showed only atropine-sensitive effects (Figure 1A and D). Among fractions, ethyl acetate and aqueous produced excitatory effects at concentrations $(0.3-3.0 \mathrm{mg} / \mathrm{mL})$ and $(0.01-5.0 \mathrm{mg} / \mathrm{mL})$, respectively. The aqueous fraction was the most potent. The effect of ethyl acetate fraction was completely blocked by atropine while partial blockade was observed on the part of aqueous fraction (Figure $1 \mathrm{~B}$ and $\mathrm{C}$ ). The mean percent maximum stimulant effects of the crude extract, its fractions and ursolic acid in rat ileum are detailed in Table III.

On mice ileum, the plant extract, its ethyl acetate, aqueous fraction and ursolic acid produced stimulatory effects similar to the effects seen in rat ileum. However, the effects were completely blocked when studied in tissues pretreated with atropine (Figure 2), indicating 
Table I

Laxative effect of $F$. indica and ursolic acid in the absence and presence of atropine in mice

\begin{tabular}{|c|c|c|c|c|}
\hline Treatment & Dose (mg/kg) & $\begin{array}{c}\text { Mean defecation/ } \\
\text { group }\end{array}$ & $\begin{array}{l}\text { Mean amount of wet } \\
\text { feces/group }\end{array}$ & $\%$ Wet feces \\
\hline Saline $(10 \mathrm{~mL} / \mathrm{kg})$ & 10 & $6.2 \pm 0.9$ & $0.8 \pm 0.3$ & 13 \\
\hline Carbachol & 1 & $11.6 \pm 0.8^{b}$ & $5.7 \pm 0.7 \mathrm{~b}$ & 48.5 \\
\hline F. indica extract & 100 & $9.5 \pm 0.5^{\mathrm{a}}$ & $3.3 \pm 0.3^{a}$ & 35 \\
\hline F. indica extract & 300 & $10.1 \pm 0.9^{b}$ & $4.34 \pm 0.5^{b}$ & 42.6 \\
\hline Ursolic acid & 10 & $7.0 \pm 0.6$ & $1.5 \pm 0.3$ & 22 \\
\hline Ursolic acid & 30 & $8.1 \pm 0.6^{a}$ & $2.9 \pm 0.4$ & 36 \\
\hline Carbachol + atropine & $1+10$ & $7.4 \pm 0.4^{\mathrm{d}}$ & $2.1 \pm 0.4^{\mathrm{d}}$ & 27.2 \\
\hline F. indica extract + atropine & $100+10$ & $4.8 \pm 0.4^{c}$ & $1.2 \pm 0.3 c$ & 28.1 \\
\hline F. indica extract + atropine & $300+10$ & $5.8 \pm 0.3^{c}$ & $1.7 \pm 0.5^{c}$ & 33.2 \\
\hline Ursolic acid + atropine & $10+10$ & $3.3 \pm 0.3 c$ & $0.2 \pm 0.1$ & 14 \\
\hline Ursolic acid + atropine & $30+10$ & $4.1 \pm 0.4^{c}$ & $1 \pm 0.0^{c}$ & 24 \\
\hline
\end{tabular}

Table II

Laxative effect of $F$. indica in loperamide-induced constipation in mice

\begin{tabular}{|c|c|c|c|c|}
\hline Treatment & Dose (mg/kg) & $\begin{array}{c}\text { Mean defecation / } \\
\text { group }\end{array}$ & $\begin{array}{l}\text { Mean amount of } \\
\text { wet feces/group }\end{array}$ & $\%$ Wet feces \\
\hline Saline $(10 \mathrm{~mL} / \mathrm{kg})$ & 10 & $8.1 \pm 0.5$ & $0.8 \pm 0.1$ & 10.2 \\
\hline Loperamide + saline & $5+10$ & $2.1 \pm 0.05^{a}$ & $0.1 \pm 0.02^{a}$ & 4.8 \\
\hline Loperamide $+F$. indica extract & $5+100$ & $4.6 \pm 0.3^{b}$ & $1.2 \pm 0.4^{b}$ & 27.3 \\
\hline Loperamide $+F$. indica extract & $5+300$ & $5 \pm 0.5^{c}$ & $1.7 \pm 0.3^{c}$ & 34.6 \\
\hline Loperamide + Ursolic acid & $5+10$ & $3.4 \pm 0.4 \mathrm{~b}$ & $0.5 \pm 0.2 \mathrm{~b}$ & 15 \\
\hline Loperamide + Ursolic acid & $5+30$ & $4.7 \pm 0.3 c$ & $1.3 \pm 0.2^{b}$ & 28 \\
\hline
\end{tabular}

the species-specific gut stimulant effects of $F$. indica. The chloroform and petroleum ether fractions of $F$. indica were found devoid of any stimulatory effects in rats and mice ileum. The mean percent maximum stimulant effects of the crude extract, its fractions and ursolic acid in mice ileum are detailed in Table IV.

The gut stimulant effect of the crude extract, its fractions and ursolic acid when reassessed in tissues pretreated with pyrilamine and methysergide, no change was observed in the resultant response compared to control responses in both rat and mice ileum preparations, hence data was not shown.

\section{Acute toxicity test}

F. indica extract at the tested doses of 3,5 and $10 \mathrm{~g} / \mathrm{kg}$ was found safe. The animals did not show any behavioral change, tremor, salivation, seizures, coma and no death was observed up to 24 hours.

\section{Discussion}

In addition to the presence of multiple phytoconstituents, the literature highlights ursolic acid as F. indica component (Atta-ur-Rahman et al., 1984) which may share diverse pharmacological activities with the parent plant. When administered to mice, F. indica and ursolic acid increased the production of wet feces and total output which was partially inhibited in mice pretreated with atropine, indicating partially atropine-sensitive laxative activities of $F$. indica and ursolic acid. Constipation refers to infrequent or difficult defecation due to slow bowel movements causing feces to remain in the intestine for longer periods. This leads to enhanced absorption of water contents from fecal material and hardening of stools. This not only produces discomfort but also causes abdominal distention, restlessness, vomiting and gut obstruction. On the other hand, test materials with the potential to increase the fecal water 


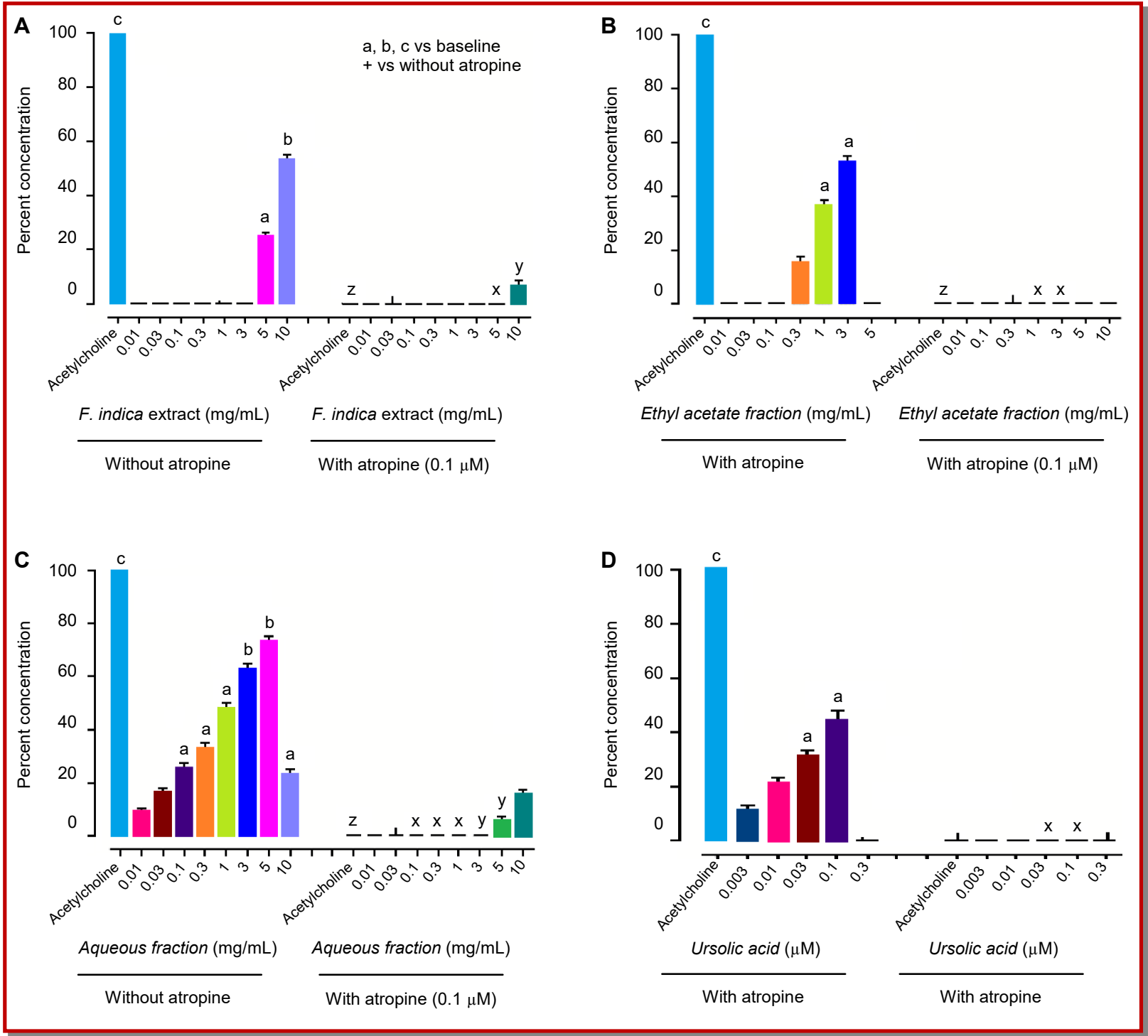

Figure 1: The concentration-dependent stimulatory effect of the crude extract of Fagonia indica (A) its ethyl acetate; (B) aqueous fractions; (C) and ursolic acid; (D) without and with atropine $(0.1 \mu \mathrm{M})$ in isolated rat ileum. Values are expressed as mean \pm SEM, $n=4-6 .{ }^{a} /{ }^{x} p<0.05, b / y p<0.01$ and $c /{ }^{z} p<0.001$. " $a, b, c$ " show comparison with baseline (One-way ANOVA tailed with Dunnett's test). " $\mathrm{x}, \mathrm{y}, \mathrm{z}$ " show comparison of atropine pretreated vs. without atropine pretreated groups (One-way ANOVA tailed with Bonferroni test)

\begin{tabular}{|c|c|c|}
\hline \multicolumn{3}{|c|}{ Table III } \\
\hline \multicolumn{3}{|c|}{$\begin{array}{c}\text { Maximum stimulatory effects of crude extract and fractions of } F \text {. indica at highest tested concentration in } \\
\text { isolated rats ileum preparation }\end{array}$} \\
\hline Test material & $\begin{array}{l}\text { Highest tested concentration } \\
\qquad(\mathrm{mg} / \mathrm{mL})\end{array}$ & $\begin{array}{l}\text { Mean }( \pm \text { SEM }) \text { \% maximum stimulatory effect, } \\
(n=4-6)\end{array}$ \\
\hline F. indica crude extract & 10 & $53.3 \pm 1.6$ \\
\hline Aqueous fraction & 5 & $73.2 \pm 1.5$ \\
\hline Ethyl acetate fraction & 3 & $51.6 \pm 1.3$ \\
\hline Chloroform fraction & - & No effect \\
\hline Petroleum ether fraction & - & No effect \\
\hline Ursolic acid & $0.1 \mu \mathrm{M}$ & $45 \pm 2.8$ \\
\hline
\end{tabular}




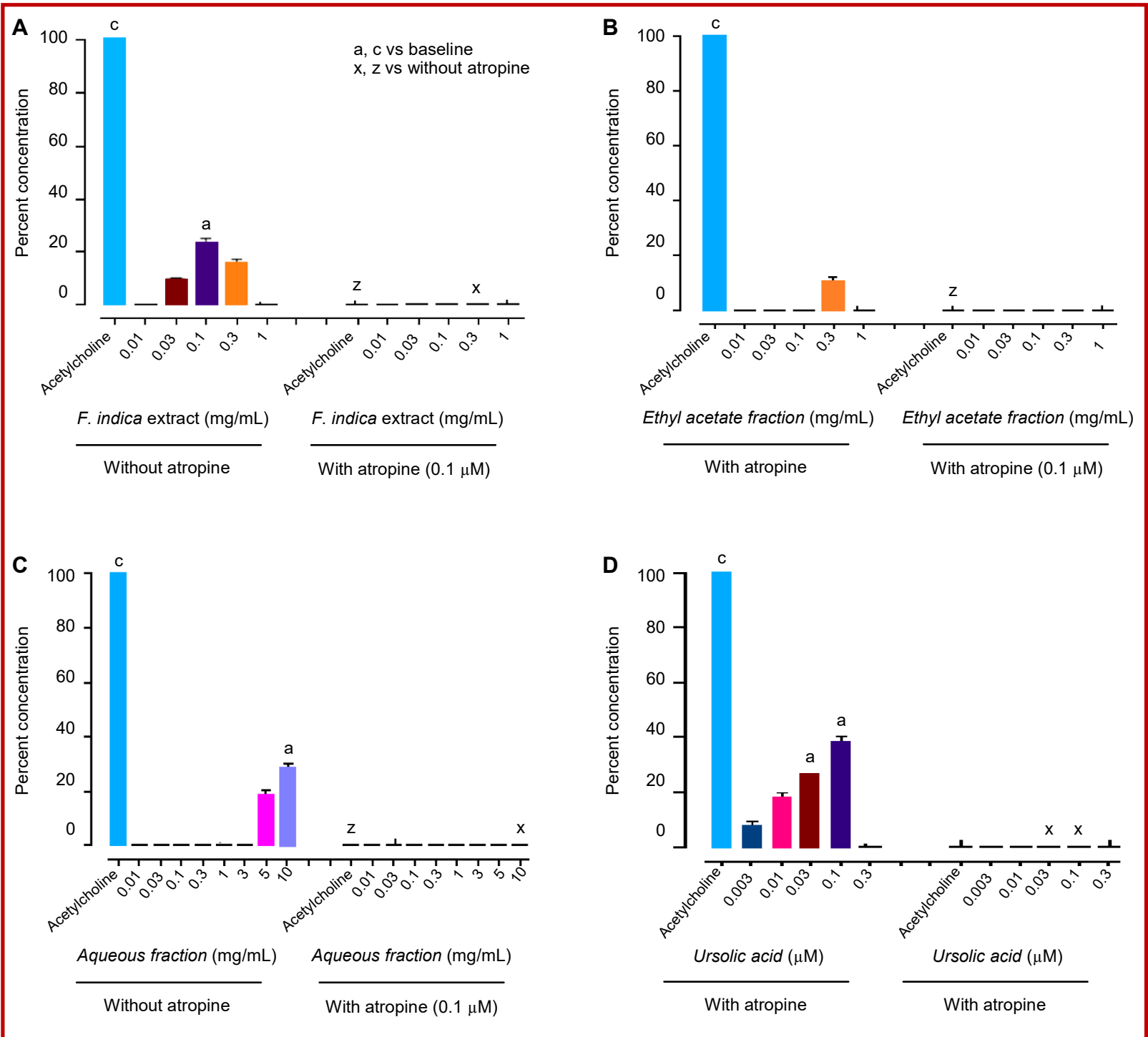

Figure 2: The concentration-dependent stimulatory effect of the crude extract of Fagonia indica (A) its ethyl acetate; (B) aqueous fractions; (C) and ursolic acid; (D) without and with atropine $(0.1 \mu \mathrm{M})$ in isolated mice ileum. Values are expressed as mean \pm $\mathrm{SEM}, \mathrm{n}=4-6 .{ }^{a} /{ }^{\mathrm{x}} \mathrm{p}<0.05$ and $\mathrm{c} /{ }^{\mathrm{z}} \mathrm{p}<0.01$. " $\mathrm{a}, \mathrm{c}^{\prime \prime}$ shows comparison with baseline (One-way ANOVA tailed with Dunnett's test). " $\mathrm{x}, \mathrm{z}$ " show comparison of atropine pretreated vs. without atropine pretreated groups (One-way ANOVA tailed with Bonferroni test)

contents and frequency are characterized as laxatives (Chatoor and Emmanuel, 2009).

Carbachol, a muscarinic agonist (Brown and Taylor, 2006), is known to accelerate gut motility through activation of muscarinic and nicotinic receptors (Unno et al., 2005) resulting in increased production of fecal output as well wet feces. A substance showing laxative effect partially sensitive to atropine, a known cholinergic receptor antagonist (Brown and Taylor, 2006), indicates the presence of partially cholinergic like gut stimulatory components mediated its laxative activity. F. indica and ursolic acid showed the presence of coexistence of partially cholinergic and some additional gut excitatory constituents mediating their laxative effects.
Loperamide is commonly employed in animal models to induce spastic constipation (Ashafa et al., 2012; Zhou et al., 2013) and is frequently used for the assessment of laxative potential of test materials. Loperamide is known to inhibit fecal mass production and delay its evacuation through inhibition of gastrointestinal secretions and motility (Hughes et al., 1984; Yamada and Onoda, 1993). In the loperamide-induced constipation mice model, F. indica extract and ursolic acid also exhibited pronounced laxative effects, thus confirming their therapeutic potential in constipation.

To further explore the insight into the mechanism of gut stimulant effects, F. indica and its fractions were tested on rat and mice ileum, reliable preparation to determine gut stimulant property with possible underlying 


\begin{tabular}{|c|c|c|}
\hline \multicolumn{3}{|c|}{ Table IV } \\
\hline \multicolumn{3}{|c|}{$\begin{array}{c}\text { Effects of crude extract and fractions of } F \text {. indica } \\
\text { in isolated mice ileum preparation }\end{array}$} \\
\hline Test material & $\begin{array}{l}\text { Maximum test- } \\
\text { ed concentra- } \\
\text { tion }(\mathrm{mg} / \mathrm{mL})\end{array}$ & $\begin{array}{l}\text { Mean }( \pm \text { SEM }) \% \\
\text { maximum stimula- } \\
\text { tory effect, }(n=4-6)\end{array}$ \\
\hline F. indica extract & 0.1 & $23.3 \pm 1.6$ \\
\hline $\begin{array}{l}\text { Aqueous frac- } \\
\text { tion }\end{array}$ & 10 & $28.3 \pm 1.3$ \\
\hline $\begin{array}{l}\text { Ethyl acetate } \\
\text { fraction }\end{array}$ & 1 & $10.6 \pm 0.6$ \\
\hline $\begin{array}{l}\text { Chloroform } \\
\text { fraction }\end{array}$ & - & No effect \\
\hline $\begin{array}{l}\text { Petroleum ether } \\
\text { fraction }\end{array}$ & - & No effect \\
\hline Ursolic acid & $0.1 \mu \mathrm{M}$ & $38.3 \pm 1.6$ \\
\hline
\end{tabular}

mechanism(s) (Unno et al., 2005; Najeeb-ur-Rehman et al., 2012). The plant extract produced specie-specific gut stimulant effects mediated partly and/or exclusively through cholinergic pathway activation, which was evident by partial blockage of the gut stimulant effect of $F$. indica extract by atropine, a cholinergic antagonist (Brown and Taylor, 2006) in rat ileum while complete blockade with atropine in mice ileum, respectively.

Polarity based solvent extraction of the crude extract of $F$. indica revealed the distribution of gut stimulatory components in aqueous and ethyl acetate fractions. Ethyl acetate fraction showed a gut stimulant effect mediated entirely through cholinergic receptors activation in rat and mice ileum preparations. However, the aqueous fraction was more potent in exhibiting partially atropine-sensitive gut stimulating effect in rat ileum and only atropine-sensitive effect in mice ileum, indicating the presence of tissue and species-specific expression of spasmogenic effect similar to the profile of parent plant. The chloroform and petroleum ether fractions were devoid of any excitatory effect in both tissues. When assessed in isolated tissues, ursolic acid also produced excitatory effects on rat and mice ileum, which was completely blocked in the presence of atropine. This is also in line with an earlier study showing its cardio-selective beneficial effects involving cholinergic receptors activation (Kim et al., 2014). These data on the part of ursolic acid strengthens the folk use of $F$. indica in constipation.

\section{Conclusion}

F. indica and its component ursolic acid possess laxative and gut stimulant effects. Laxative effects are mediated partially through the activation of cholinergic receptor. The gut stimulant effect is found specie-specific in rat (partially cholinergic) and mouse (exclusively cholinergic).

\section{Ethical Issue}

Laboratory animals handling was carried out following the rulings of the Institute of Laboratory Animal Resources Commission on Life Sciences, National Research Council (1996). The prior approval of the study protocol received from the Institutional Review Board, Government College University Faisalabad, Punjab, Pakistan vide letter No. IRB/ 583 dated 26-06-2018.

\section{Conflict of Interest}

The authors of this manuscript declare no conflicts of interest regarding its publication.

\section{Acknowledgement}

We are thankful to the staff of animal house and research laboratory of Department of Pharmacology, Faculty of Pharmaceutical Sciences, Government College University, Faisalabad, for kind and valuable support.

\section{References}

Ageely HM, Gupta SK, Latif MA, Patil BR. Review of Ethnomedicinal Plant Fagonia. Int J Pharm Pharm Sci. 2014; 5: 22-28.

Ahmad S, Wariss HM, Alam MK, Anjum S, Ahmad K, Akhtar N. Hydro-alcoholic extracts of Fagonia indica Burm. f. contribute anti-pyrexia activity to E. coli exposure in rabbits. Int J Sci Res. 2014; 3: 215-18.

Arshad U, Janbaz KH, Bashir S, Rehman NU, Mehmood MH, Gilani AH. Ethnopharmacological studies on Chrozophora prostrate in perspective of its folkloric reputation as purgative. Bangladesh J Pharmacol. 2012; 7: 243-48.

Ashafa AOT, Yakubu MY, Ogbe AAA, Abass AA. Effect of ethanolic seed extract of Croton penduliflorus Hutch. on loperamide-induced constipated male rats. Bangladesh J Pharmacol. 2012; 7: 42-46.

Atta-ur-Rahman, Ansari AA, Kenne L. Hederagenin, ursolic acid, and pinatol from Fagonia indica. J Nat Prod. 1984; 47: 186-87.

Azam F, Sheikh N, Ali G, Tayyeb A. Fagonia indica repairs hepatic damage through expression regulation of toll-like receptors in a liver injury model. J Immunol Res. 2018; 12: 113.

Brown JH, Taylor P. Muscarinic receptor agonists and antagonists In: Goodman and Gilman's The Pharmacological basis of therapeutics. Hardman JG, Limbird LE, Molinoff PB, Ruddon RW, Gilman AG (eds). 10th ed. New York, McGraw -Hill, 2006, pp 141-60.

Chatoor D, Emmanuel A. Constipation and evacuation disorders. Best Pract Res Clin Gastroenterol. 2009; 23: 517-30.

Eman AA. Morphological, phytochemical and biological screening on three Egyptian species of Fagonia. Academia Arena. 2011; 3: 18-27. 
Farheen R, Mahmood I, Siddiqui BS, Mahmood T, Wahab A. Fagonilin: A new triterpene from Fagonia indica Burm. F. Var. indica. Fuuast J Biol. 2014; 4: 261-64.

Ghayur MN, Gilani AH. Pharmacological basis for the medicinal use of ginger in gastrointestinal disorders. Dig Dis Sci. 2005; 50: 1889-97.

Gulshan AB, Dasti AA, Hussain S, Atta MI, Amin-ud-Din M. Indigenous uses of medicinal plants in rural areas of Dera Ghazi Khan, Punjab, Pakistan. J Agric Biol Sci. 2012; 7: 75059.

Hughes S, Higgs NB, Turnberg LA. Loperamide has antisecretory activity in the human jejunum in vivo. Gut 1984; 25 : 931-35.

Hussain M, Raza SM, Janbaz KH. Pharmacological evaluation and validation for the folkloric use of Oligochaeta ramosa in constipation and diarrhea. Bangladesh J Pharmacol. 2014; 9: 617-23.

Kakino M, Izuta H, Ito T. Agarwood induced laxative effects via acetylcholine receptors on loperamide-induced constipation in mice. Biosci Biotechnol Biochem. 2010; 74: 1550-55.

Kasture VS, Gosavi SA, Kolpe JB, Deshapande SG. Phytochemical and biological evaluation of Fagonia species: A review. Int J Pharm Pharm Sci. 2014; 3: 1206-17.

Lee HY, Kim JH, Jeung HW. Effects of Ficus carica paste on loperamide-induced constipation in rats. Food Chem Toxicol. 2012; 50: 895-902.

Mehmood MH, Anila N, Begum S, Syed SA, Siddiqui BS, Gilani AH. Pharmacological basis for the medicinal use of Carissa carandas in constipation and diarrhea. J Ethnopharmacol. 2014; 153: 359-67.

Mehmood MH, Aziz N, Ghayur MN, Gilani AH. Pharmacological basis for the medicinal use of Psyllium husk (Ispaghula) in constipation and diarrhea. Dig Dis Sci. 2011; 56: 1460-71.

Mehmood MH, Aziz N, Ghayur MN, Gilani AH. Pharmacological basis for the medicinal use of Psyllium husk
(Ispaghula) in constipation and diarrhea. Dig Dis Sci. 2011; 56: 1460-71.

Najeeb-ur-Rehman, Mehmood MH, Adnan J, Al-Rehaily AJ, Ramzi AA, Mothana, Gilani AH. Species and tissuespecificity of prokinetic, laxative and spasmodic effects of Fumaria parviflora. BMC Complement Altern Med. 2012; 12: $16-24$.

Sharma S, Joseph L, George M, Gupta V. Analgesic and antimicrobial activity of Fagonia indica. Pharmacologyonline 2009; 3: 623-32.

Shehab NG, Abu-Gharbieh E, Bayoumi FA. Impact of phenolic composition on hepatoprotective and antioxidant effects of four desert medicinal plants. BMC Complement Altern Med. 2015; 15: 401-13.

Soliman SSM, Semreen MH, El-Keblawy AA, Abdullah A, Uppuluri P, Ibrahim AS. Assessment of herbal drugs for promising anti-Candida activity. BMC Complement Altern Med. 2017; 17: 257.

Unno T, Matsuyama H, Sakamoto T, Uchiyama M, Izumi $\mathrm{Y}$, Okamoto H, Yamada M, Wess J, Komori S. $\mathrm{M}_{2}$ and $\mathrm{M}_{3}$ muscarinic receptor-mediated contractions in longitudinal smooth muscle of the ileum studied with receptor knockout mice. Br J Pharmacol. 2005; 146: 98-108.

Victor ON, Chidi O. Phytochemical constituents of some selected medicinal plants. Afr J Pure Appl Chem. 2009; 3: 228-33.

Waheed A, Barker J, Barton SJ, Owen CP, Ahmed S, Carew MA. A novel steroidal saponin glycoside from Fagonia indica induces cell-selective apoptosis or necrosis in cancer cells. Eur J Pharm Sci. 2012; 47: 464-73.

Yamada K, Onoda Y. Comparison of the effects of T-1815, yohimbine and naloxone on mouse colonic propulsion. J Smooth Muscle Res. 1993; 29: 47-53.

Zhou M, Jia P, Chen J, Xiu A, Zhao Y, Zhan Y, Chen P, Zhang J. Laxative effects of Salecan on normal and two models of experimental constipated mice. BMC Gastroenterol. 2013; 13: 52. 